技術論文

\title{
$\mathrm{ADAMS}$ 를 이용한 항공기 착륙장치 작동 동적거동 해석
}

최 섭*, 권혁범*, 정상준*, 정창래*, 성덕용**

\section{An operational analysis and dynamic behavior for a landing gear system using ADAMS}

Sup Choi*, Hyuk Beom Kwon*, Sang Joon Chung*, Chang Rae Jung* and Duck Yong Sung*

\begin{abstract}
The operational characteristics of the landing gear retraction/extension depend on the complexity of design variables operational/environmental conditions. In order to meet the requirements of minimum stow area and performance, the integration of the landing gear system requires operational kinematic and dynamic analysis considering an effect of its related system.

This study investigates operational dynamic behaviors of the T-50 landing gear system using ADAMS. Taking into account for various operational/environmental conditions, an analysis of dynamic behavior on the landing gear operational characteristics is performed with experience derived from a wide range of proprietary designs. Analytical results are presented for discussing the effects of temperature, aerodynamic and maneuver load on normal/emergency operation of the landing gears and doors. This analysis leads us to the conclusion that the proposed program is shown to be a better quantitative one that apply to a new development and troubleshooting of the landing gear system.

\section{초 록}

착륙장치 시스템의 올림/내림 작동특성은 다양한 설계변수, 운용조건 및 환경조건에 따 라 변화한다. 최소한의 작동공간 및 성능 요구조건을 만족하기 위하여, 착륙장치 시스템은 관련계통의 영향성을 고려하여 기구학적/동역학적 작동해석이 요구된다.

본 연구에서는 T-50 착륙장치를 모델로 ADAMS를 이용하여 착륙장치 작동에 따른 동 적거동을 해석할 수 있는 프로그램을 개발하였다. 설계변수 설정, 유압 압력/유량의 관계 정의, 운동방정식을 유도하여 공력하중, 기동하중, 온도의 영향에 대한 착륙장치 및 덮개문 의 정상/비상 작동 동적거동 해석결과를 제시하고 분석하였다. 이러한 해석결과를 바탕으 로 향후 새로운 착륙장치 개발시 범용적인 해석이 용이할 뿐만 아니라 지상/비행시험의 문제점 발생시 고장탐구 해결에 활용할 수 있다.
\end{abstract}

Key words : landing gears and doors(착륙장치 및 덮개문), ADAMS, actuators(작동기), operational dynamic behavior(작동 동적거동), retraction/extension(올림/내림)

† 2003년 1월 18일 접수 2003년 3월 6일 심사완료

* 정회원, 국방과학연구소

I. 서 론

연락저자, E-mail : chs1109add@yahoo.co.kr

대전시 유성우체국 사서함 35-3호

** 정회원, 공군 
한의 작동공간에서 작동성이 보장되도록 규정하고 있다[1]. 이를 만족하기 위하여 복잡한 기구설계가 도입됨에 따라 운용도중 고장 발생률이 빈번한 시 스템으로 구분되고 있다.

현재 개발중인 T-50 주륜 착륙장치의 경우, 올 림상태에서 장착공간을 최소화하기 위해 접힙과정 중 타이어의 방향을 전환하는 기구설계를 적용하 고 있다. 이러한 기구학적 특성은 관련계통 (전기/ 유압시스템 등)과의 적합성을 보장하기 위하여 작 동 동적거동을 고려하여야 한다. 또한 KT-1 선행 개발 과정에서 착륙장치의 정상적인 올림 작동속 도가 제한된 경험을 한 바 있다[2]. 따라서, 항공기 기동조건, 공력하중, 관련계통의 성능을 고려하여 다양한 운용/환경조건에 대한 착륙장치 및 덮개문 의 작동해석은 기구학적/동역학적 특성에 대한 보 다 엄밀한 해석이 선행되어야 한다. 작동시간 및 작동한계를 고려한 올림/내림작동 동적거동은 착 륙장치 자체 구성품 뿐만 아니라 관련계통 설계에 영향을 미치는 중요한 설계분야이다. 이러한 해석 결과를 바탕으로 설계요구조건의 만족 여부 확인 및 작동성 예측이 가능하고 동시에 항공기 비행시 험에 대한 위험요소를 사전에 제거할 수 있다.

현재까지의 연구동향은 정상준[3] 등이 KT-1 착 륙장치를 모델로 정적 해석을 수행하여 작동기구 의 설계 타당성을 확인하였다. 임철호[4] 등은 유 압시스템 해석용 소프트웨어인 HyPneu를 활용하 여 압력/유량 등에 대한 해석을 수행하여 설계요 구조건 만족여부를 확인하고 유압시스템 주요부품 의 용량을 결정하였다. 이러한 해석방법은 개발과 정상 반복되는 설계 변경에 따라 모델링이 다시 필요한 어려움이 있다.

최근 들어 해외 항공기 제작사와 착륙장치 전문 업체들은 이와 같은 단점을 보완하기 위하여, 상 용 프로그램을 활용하여 해석도구로 적용하고 있 는 실정이다[5]. Noel[6]과 Zhang[7]등은 동력학 해석 범용 소프트웨어인 ADAMS (Automatic Dynamic Analysis of Mechanical System)을 사용 하여 착륙장치 구동기구의 동적 해석을 수행하고 설계도구로 활용 방안을 제시하였다.

기존의 연구결과를 바탕으로 본 연구에서는 착 륙장치 시스템 개발시 범용적인 해석도구로 활용 하고자 $\mathrm{ADAMS}$ 를 이용하여 다양한 운용/환경조 건을 고려한 착륙장치 시스템작동에 따른 동적거 동을 예측할 수 있는 프로그램을 개발하였다.

\section{II. 해석모델}

\section{1 모델링}

착륙장치 시스템의 작동 동적거동을 해석하기 위해 ADAMS를 이용하여 강체로 모델링 하였 다. $\mathrm{ADAMS}$ 강체 모델을 수행하는데 필요한 입 력자료는 각 강체의 무게, 무게중심, 관성모멘트 등의 물성치와 강체들을 연결하고 있는 스프링, 댐퍼, 조인트 등의 특성치 자료가 필요하다[8,9]. 본 연구에서는 설계단계에서 확보한 실제 값들을 사용하였으며, 연결 요소에 대한 특성치는 해외 전문업체에서 적용하는 경험치를 사용하였다. 또 한, 해석대상으로는 주륜 착륙장치 (main landing gear) 및 전륜 착륙장치(nose landing gear), 주륜 덮개문(main door) 및 전륜 덮개문 (nose door)에 대하여 각각 올림/내림/비상내림 의 작동을 고려하였다[5].

Fig. 1은 T-50 주륜 착륙장치로 완충기, 트레일 링 암 (trailing arm), 작동기 (brace actuator) 등 으로 구성되며, 전륜 착륙장치 및 덮개문을 포함 하여 27 개의 강체와 35 개의 조인트로 모델링 하 였다[5].

\section{2 하중조건}

\subsection{1 기동조건}

착륙장치 및 덮개문에 작용하는 기동하중은 항공기 운용속도와 올림/내림 (Retraction/ Extension)의 조건에 따라 다르게 적용하였다. 올 림상태에서는 항공기 속도와 상관없이 $1 \mathrm{G}$ down 과 $1 \mathrm{G}$ back, 내림상태에서는 항공기 속도를 고 려하여 $1 \mathrm{G} \sim 4 \mathrm{G}$ down 기동조건을 적용하였다.

\subsection{2 공력하중}

착륙장치 및 덮개문에 작용하는 공력하중은 착륙속도 및 자세, 구조물의 형상에 따라 변화하 며 아래 식 (1)으로 표현된다.

$$
F_{\text {aero }}=K V^{2}=\frac{1}{2} \rho \frac{A}{g} C_{x} V^{2}
$$

여기서, $A$ 는 공력 단면적, $C_{x}$ 는 상수로 0.3 (올림), 0.8 (내림)로 가정하였으며, $V$ 는 항공기 속도, $\rho$ 는 공기 밀도이다.

Fig. 2 및 3은 각각 착륙장치 올림/내림중 유 압작동기의 스트로크에 대한 주륜 착륙장치 완충 기와 타이어의 공력하중을 받는 면적을 나타낸 다. 완충기에 해당하는 면적은 작동방향의 투영 면적으로 내림상태에서 최대값을 갖고 올림상태 에서는 공력하중이 작용하지 않음을 알 수 있다. 반면, 올림상태에서 장착공간을 최소화하기 위하 여 접힘과정중 타이어의 방향이 변화하도록 설계 한 작동기구을 고려 작동기 스트로크에 따라 변 화하는 특성을 Fig. 3에 나타내었다. 
Fig. 4는 주륜 덮개문의 작동각도에 대한 공력 하중의 크기를 항공기 속도에 대하여 나타낸 것 으로 덮개문 닫힘시 공력하중이 감소하는 것은 식(1)의 공력 단면적 $(A)$ 이 감소하기 때문이다.

\section{III. 시스템 특성}

착륙장치의 내림 및 올림 작동은 항공기 엔진 의 동력을 이용하는 유압펌프로부터 생성되는 $3,000 \mathrm{psi}$ 의 시스템 압력 및 유량에 의하여 결정 된다. 엔진의 작동불량이나 항공기 유압계통의 문제점 발생시 고압으로 충전되어 있는 비상축압 기를 이용하여 덮개문을 작동하고, 착륙장치는 자중에 의해 내림작동을 하게 된다.

\subsection{1 유압 회로 작동 특성}

본 연구에서 적용한 착륙장치 시스템의 유압 회로는 Fig. 5 와 같이 유압시스템의 공급 및 회 송라인과 연결되어 있는 유압다기관은 착륙장치 및 덮개문 작동기와 각각 연결되어 있다. 정상작 동의 경우 조종실의 선택에 따라 유압다기관의 선택밸브를 조절하여 착륙장치 및 덮개문 작동기 에 유압이 형성되어 올림/내림 작동을 한다. 반 면 비상작동의 경우 비상축압기의 공기압을 이용 하여 덮개문 작동기를 작동하고 착륙장치는 자중 에 의해 내림작동을 한다.

\subsection{2 압력손실}

압력손실은 유압다기관에서의 압력손실, 유압 배관상의 압력손실 및 작동기의 제한기 압력손실 로 분류하였다. 초기 공급압력 및 회송압력은 일 정하다고 가정한 상태에서 작동기 챔버의 압력은 공급압력에서 구간별 압력손실을 고려하여 식 (2)로 표현할 수 있다.

$$
\begin{gathered}
P_{\text {supply }}=P_{o}-\Delta P_{\text {bloc }}-\Delta P_{\text {bite }}-\Delta P_{\text {damping }}(2) \\
P_{\text {return }}=P_{\text {rev }}+\Delta P_{\text {bloc }}+\Delta P_{\text {pipe }}+\Delta P_{\text {damping }}
\end{gathered}
$$

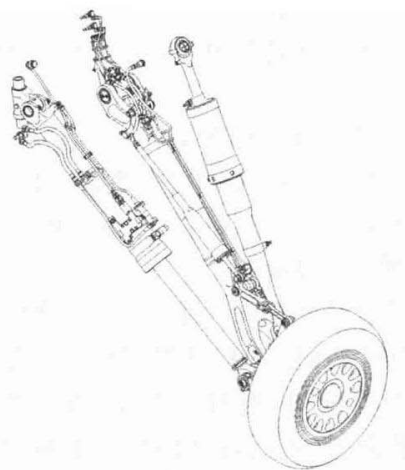

Fig. 1. Schematic model of the T-50 main landing gear system.

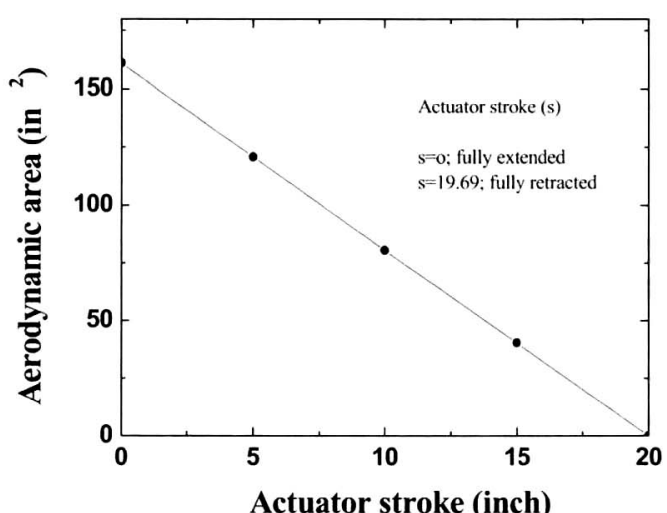

Fig. 2. Aerodynamic area of the main landing gear shock strut.

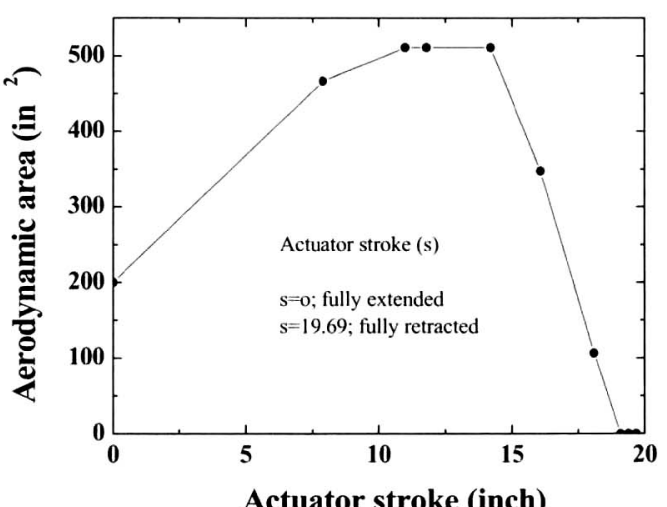

Fig. 3. Aerodynamic area of the main landing gear tire and wheel.

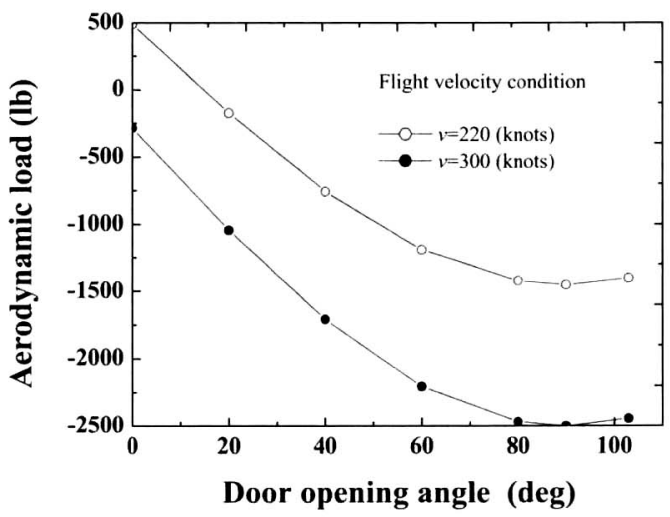

Fig. 4. Aerodynamic force acting on the MLG door with various flight condition.

유압 다기관에서의 압력손실은 $\operatorname{Lohm}(L)$ 값을 도입하여 식 (3)으로 표현된다.

$$
\Delta P_{\text {bloc }}=S L^{2} Q^{2} /\left(K^{2} \nu^{2}\right)
$$




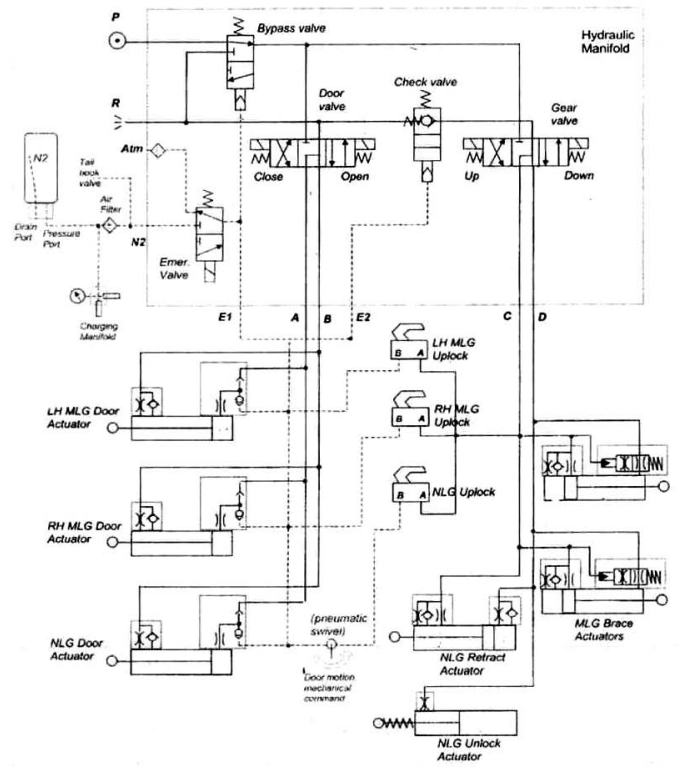

Fig. 5. Schematic hydraulic diagram of landing gear system.

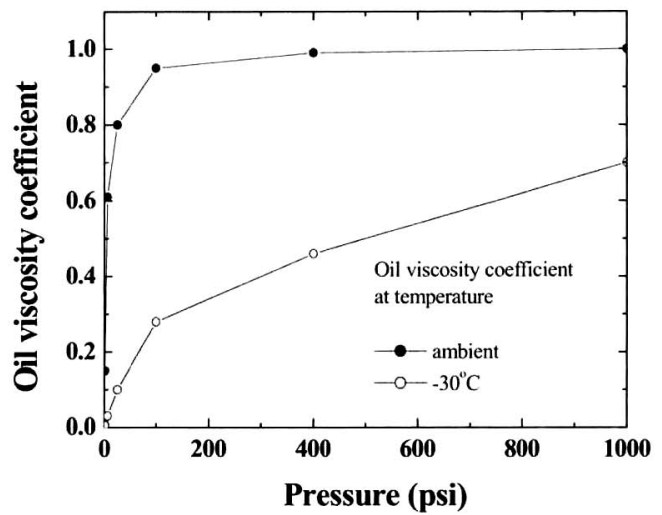

Fig. 6. Variation of the oil viscosity coefficient with various of temperature.

여기서, $\nu$ 는 Viscosity coefficient, $K$ 는 Units constant-liquid, $S$ 는 Specific gravity, $L$ 은 Lohm 값, $Q$ 는 total flowrate $\left(\mathrm{in}^{3} / \mathrm{sec}\right)$ 이다. 일반적으로 점성계수 $\nu$ 는 온도와 압력의 함수로 Fig. 6에 나타내었다.

배관내의 압력손실은 레이놀즈수 $(\mathrm{Re})$ 가 2,000 보다 작다고 가정하고 식 (4)를 사용하여 구간별 압력손실을 계산하였다.

$$
\Delta P_{\text {pipe }}=\frac{128 \times \rho \times \nu \times l \times Q}{\pi \times d_{i}{ }^{4}}
$$

여기서 $\Delta P$ 는 압력손실(psi), $\rho$ 는 유압유 밀도 $\left(\mathrm{lb} / \mathrm{in}^{3}\right), \nu$ 는 동점성계수(stokes), $l$ 은 파이프 길 이, $Q$ 는 유량 $\left(\mathrm{in}^{3} / \mathrm{sec}\right), d_{i}$ 는 배관 내경(in)이다.

작동기 챔버의 입/출구에는 제한기를 장착하 여 작동기 속도를 제어하고, 이로 인한 압력손실 은 식(5)와 같이 속도의 함수로 표현된다.

$$
\Delta P_{\text {damping }}=K_{i} V^{2}=\frac{1}{2 g} \rho\left(\frac{C_{n}}{\sigma_{i}}\right)^{2} V^{2}
$$

여기서 $V$ 는 작동기 속도 (in/sec), $\rho$ 는 유압유 밀도 $\left(\mathrm{lb} / \mathrm{in}^{3}\right), \sigma_{i}$ 는 작동기 입/출력시 제한기 오 리피스 단면적, $C_{n}$ 은 작동기 단면적이다.

\section{IV. 결과 및 토의}

본 해석에서는 다양한 운용/환경조건에서 착 륙장치 올림/내림 및 덮개문의 닫힘/열림의 동 작을 정상 및 비상작동에 대하여 해석하고 결과 를 분석하였다.

\begin{tabular}{|c|c|c|c|c|}
\hline \multicolumn{4}{|c|}{ 해 석 조 건 } & \multirow{2}{*}{$\begin{array}{c}\text { 올림시간 } \\
\text { (sec) }\end{array}$} \\
\hline \multicolumn{2}{|r|}{ 상 태(Condition) } & 속도(kts) & 온도 $\left({ }^{\circ} \mathrm{C}\right)$ & \\
\hline \multirow{2}{*}{1} & MLG 정상 올림 & 200 & 25 & 4.4 \\
\hline & NLG 정상 올림 & 200 & 25 & 4.0 \\
\hline \multirow{2}{*}{2} & MLG 올림 (고속상태) & 300 & 25 & 4.75 \\
\hline & NLG 올림 (고속상태) & 300 & 25 & 4.4 \\
\hline \multirow{2}{*}{3} & MLG 올림 (저속상태) & 127 & 25 & 4.3 \\
\hline & NLG 올림 (저속상태) & 127 & 25 & 3.9 \\
\hline \multirow{2}{*}{4} & MLG 올림 (Jacking) & 0 & 25 & 4.1 \\
\hline & NLG 올림 (Jacking) & 0 & 25 & 3.7 \\
\hline \multirow{2}{*}{5} & 저온 MLG 올림 & 200 & -30 & 6.9 \\
\hline & 저온 NLG 올림 & 200 & -30 & 5.7 \\
\hline
\end{tabular}

Table 1. Results of normal retraction

Table 2. Results of normal extension

\begin{tabular}{|c|c|c|c|c|}
\hline \multicolumn{4}{|c|}{ 해 석 조 건 } & \multirow{2}{*}{$\begin{array}{c}\text { 내림시간 } \\
\text { (sec) }\end{array}$} \\
\hline \multirow{2}{*}{1 상 태(Condition) } & 속도(kts) & 온도 ( $\left.{ }^{\circ} \mathrm{C}\right)$ & \\
\cline { 1 - 4 } & MLG 정상 내림 & 200 & 25 & 4.7 \\
\cline { 2 - 4 } & NLG 정상 내림 & 200 & 25 & 3.9 \\
\hline \multirow{2}{*}{2} & MLG 내림 (고속상태) & 300 & 25 & 4.4 \\
\cline { 2 - 4 } & NLG 내림 (고속상태) & 300 & 25 & 3.4 \\
\hline \multirow{3}{*}{3} & MLG 내림 (저속상태) & 127 & 25 & 4.7 \\
\cline { 2 - 4 } & NLG 내림 (저속상태) & 127 & 25 & 4.0 \\
\hline \multirow{3}{*}{4} & MLG 내림 (Jacking) & 0 & 25 & 4.8 \\
\cline { 2 - 4 } & NLG 내림 (Jacking) & 0 & 25 & 4.0 \\
\hline \multirow{2}{*}{5} & 저온 MLG 내림 & 200 & -30 & 5.9 \\
\cline { 2 - 4 } & 저온 NLG 내림 & 200 & -30 & 5.2 \\
\hline
\end{tabular}


Table 1과 2는 착륙장치 올림 및 내림에 대한 해석결과로, 전륜 착륙장치의 경우 항공기 속도 가 정지조건에서 올림/내림 작동시간이 각각 $3.7 / 4.0$ 초이고, 항공기 속도가 $300 \mathrm{kts}$ 인 경우에 는 4.4/3.4초로 항공기 정지조건 대비 올림시간 은 $19 \%$ 증가하고 내림시간이 $16 \%$ 감소하였다. 주륜 착륙장치의 경우에도 $16 \%$ 올림시간이 증가 하였고 $7 \%$ 의 내림시간이 단축되었다. 항공기 속 도가 클수록 주륜 및 전륜 착륙장치의 올림 작동 시간이 증가하고 내림 작동시간이 감소함을 확인 할 수 있다.

저온 환경조건 $\left(-30^{\circ} \mathrm{C}\right)$ 하에서의 착륙장치 올림 및 내림시간의 작동시간은 상온조건 하에서의 작 동시간보다 증가한다. 따라서 저온의 영향은 착 륙장치 시스템의 작동시간을 증가시킴을 알 수 있다.

비상시 착륙장치 덮개문은 비상축압기의 공압 에 의해 작동되고 착륙장치는 자중에 의해 내려 간다. Table 3은 비상시의 착륙장치 내림에 대한 해석결과로 정지속도에서 전륜 착륙장치의 경우 내림시간이 16.1초인데 반해서 항공기 속도가 $300 \mathrm{kts}$ 인 경우 내림시간이 5.2초로 감소하였다. 이는 착륙장치 내림작동에서는 공력하중이 작동 방향으로 작용함으로써 착륙장치 내림에 유리하 게 작용함을 알 수 있다. 반면 주륜 착륙장치는 공력하중이 작용하지 않는 정지상태의 항공기인 경우 내림잠금(downlock)이 되지 않음을 확인하 였다. 이는 비행시험전 착륙장치의 정상/비상 작 동성 확인이 불가능하므로 개발인증시험 및 항공 기 지상시험에서 보다 세심한 검토가 요구된다.

Table 4는 착륙장치 덮개문 올림/내림이 작동 성에 대한 해석결과로 전륜 덮개문의 경우 항공 기가 정지상태인 경우 닫힘/열림시간이 각각1.5 초/2.2초이다. 항공기 속도 $300 \mathrm{kts}$ (limit 조건) 의 경우 2.7 초 $/ 1.9$ 초로 $80 \%$ 의 닫힘 시간이 증가 한 반면 $14 \%$ 의 열림 시간이 감소되었다. 주륜 덮개문의 경우에도 $53 \%$ 닫힘 시간이 증가하고 $15 \%$ 의 열림 시간이 감소되었다. 이러한 결과로 부터 항공기 속도가 증가함에 따라 공력의 영향 으로 덮개문 닫힘 시간이 증가하고 열림 시간이 감소함을 알 수 있다.

온도가 $-30^{\circ} \mathrm{C}$ 인 경우 착륙장치와 마찬가지로 닫힘 및 열림 시간이 증가한다. 주륜덮개문의 경 우 닫힘시 1.8 초에서 3.2 초로 증가하고, 열림시 2 초에서 2.6초로 증가하며, 전륜 덮개문의 경우 닫 힘시 1.8 초에서 3.6 초로 증가하고, 열림시 1.2초에 서 1.6초로 증가하였다. 저온의 영향은 덮개문의 작동시간에 매우 불리하게 작용함을 알 수 있고,
Table 3. Results of emergency extension

\begin{tabular}{|c|c|c|c|c|}
\hline \multicolumn{4}{|c|}{ 해 석 조 건 } & \multirow{2}{*}{$\begin{array}{c}\text { 내림시간 } \\
\text { (sec) }\end{array}$} \\
\hline \multicolumn{2}{|r|}{ 상 태(Conditions) } & 속도(kts) & 온도 $\left({ }^{\circ} \mathrm{C}\right)$ & \\
\hline \multirow{2}{*}{1} & MLG 내림 & 200 & 25 & 8.1 \\
\hline & NLG 내림 & 200 & 25 & 10.6 \\
\hline \multirow{2}{*}{2} & $\begin{array}{l}\text { MLG 내림 } \\
\text { (고속상태) }\end{array}$ & 300 & 25 & 3.6 \\
\hline & $\begin{array}{l}\text { NLG 내림 } \\
\text { (고속상태) }\end{array}$ & 300 & 25 & 5.2 \\
\hline \multirow{2}{*}{3} & $\begin{array}{l}\text { MLG 내림 } \\
\text { (저속상태) }\end{array}$ & 127 & 25 & 10.9 \\
\hline & $\begin{array}{l}\text { NLG 내림 } \\
\text { (저속상태) }\end{array}$ & 127 & 25 & 12.6 \\
\hline \multirow{2}{*}{4} & MLG 내림 (Jacking) & 0 & 25 & no downlock \\
\hline & NLG 내림 (Jacking) & 0 & 25 & 16.1 \\
\hline
\end{tabular}

Table 4. Results of MLG/NLG doors

\begin{tabular}{|c|c|c|c|}
\hline & 해 석 조 건 & $\begin{array}{c}\text { 작동시간 } \\
\text { (sec) }\end{array}$ & $\begin{array}{c}\text { 유량 } \\
\end{array}$ \\
\hline 1 & $\mathrm{MLG}$ Door 정상 닫힘 & 1.8 & 480 \\
\hline & NLG Door 정상 닫힘 & 1.8 & \\
\hline 2 & MLG Door 닫힘 (고속상태) & 2.7 & 373 \\
\hline & NLG Door 닫힘 (고속상태) & 2.3 & \\
\hline 3 & MLG Door 닫힘 (Jacking) & 1.5 & 142 \\
\hline 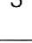 & NLG Door 닫힘 (Jacking) & 1.5 & 44.2 \\
\hline 1 & 저온 MLG Door 닫힘 & 3.2 & 206 \\
\hline 4 & 저온 NLG Door 닫힘 & 3.6 & 29.0 \\
\hline 5 & MLG Door 정상 열림 & 2.0 & 51 \\
\hline$J$ & NLG Door 정상 열림 & 1.2 & J.0 \\
\hline 6 & MLG Door 열림 (고속상태) & 1.9 & 533 \\
\hline & NLG Door 열림 (고속상태) & 1.1 & \\
\hline 7 & MLG Door 열림 (Jacking) & 2.2 & 167 \\
\hline r & NLG Door 열림 (Jacking) & 1.3 & 40.1 \\
\hline 8 & 저온 MLG Door 정상 열림 & 2.6 & 403 \\
\hline & 저온 NLG Door 정상 열림 & 1.6 & 40.3 \\
\hline 9 & MLG Door 비상 열림 & 1.99 & \\
\hline & NLG Door 비상 열림 & 0.9 & \\
\hline 10 & MLG Door 비상열림(고속상태) & 1.8 & \\
\hline 10 & NLG Door 비상열림 (고속상태) & 0.8 & $\begin{array}{l}\text { 비상시 } \\
\text { 고ㅇㅏㅏ }\end{array}$ \\
\hline 11 & MLG Door 비상열림 (Jacking) & 2.2 & 공급 \\
\hline & NLG Door 비상열림 (Jacking) & 1.0 & \\
\hline 12 & 저온 MLG Door 비상 열림 & 2.5 & \\
\hline & 저온 NLG Door 비상 열림 & 1.1 & \\
\hline
\end{tabular}

특히 덮개문을 닫는 작동의 경우에는 약 2 배로 작동시간이 증가함을 알 수 있다. 이는 식(3), (5) 에 나타낸 바와 같이 유압손실은 Fig. (6)에 나타 낸 온도의 함수인 유압유의 점성과 밀도에 비례 
하기 때문으로 설명할 수 있다. 따라서 착륙장치 시스템 설계시 덮개문 작동에 대한 공력하중 및 온도의 영향이 충분히 고려되어야 한다.

Table 4에서 최대 공급유량은 항공기 유압 시 스템의 공급조건인 $50 \quad \mathrm{in}^{3} / \mathrm{sec}$ (닫힘) 및 53 $\mathrm{in}^{3} / \sec$ (열림) 내에서 작동함을 알 수 있다. 다만 고속상태에서 덮개문 열림상태의 하중조건의 경 우 요구치를 $0.6 \%\left(0.3 \mathrm{in}^{3} / \mathrm{sec}\right)$ 초과한다. 이는 항 공기 유압시스템의 공급유량이 만족되지 않는 경 우로 공급유량이 부족하게 됨에 따라 작동기의 속도가 감소되어 덮개문의 내림 시간이 본 해석 결과보다 약간 증가하게 될 것으로 예상된다.

\section{1 덮개문에 대한 공력하중의 영향}

Fig. 7은 다양한 항공기 속도조건에서 주륜덮 개문의 닫힘작동시 작동력으로 항공기 속도가 클 수록 작동력이 증가하고 음부호(-)의 하중은 작동 기가 접힘(retraction) 작동을 하는 것을 의미한 다. 덮개문 열림 각도가 줄어들수록 작동기의 작 동력이 감소하는데, 이는 덮개문의 공기역학적 단면적에 비례하는 공력이 감소하여 작동력이 감 소하기 때문이다.

Fig. 8은 주륜덮개문의 열림작동시 작동기는 공력 및 기동하중에 의해 열리는 덮개문의 열림 하중이 크고 속도가 상대적으로 크기 때문에 작 동기의 피스톤을 끌고 가게 됨에 따라 작동기는 펼침상태이나 작동력은 덮개문 운동방향의 반대 방향으로 작용하여 작동력은 음부호(-)로 나타남 을 알 수 있다.

\section{2 착륙장치에 대한 공력하중의 영향}

Fig. 9, 10은 각각 다양한 항공기 속도조건에서 주륜 착륙장치의 올림 작동시 작동기 챔버내 압 력 및 작동력을 나타낸다.

Fig. 9는 작동기의 공급챔버 $\left(P_{1}\right)$ 및 배출챔버 $\left(P_{2}\right)$ 의 압력관계로 항공기 속도가 클수록 주륜 작동기 공급챔버와 배출챔버의 압력차는 증가하 여 작동력이 증가함을 확인할 수 있다. $\mathrm{A}$ 와 $\mathrm{B}$ 의 표시는 각각 항공기 속도 $220,330 \mathrm{kts}$ 경우의 올 림 작동시간으로 항공기 속도가 클수록 착륙장치 올림 시간이 증가함을 알 수 있다.

Fig. 10은 Fig. 9의 압력관계를 작동기 스트로 크 대비 작동력으로 항공기 속도가 큰 경우 작동 력이 커짐을 알 수 있다. 주륜 착륙장치가 올라 감에 따라 초기에는 작동력이 점점 증가하다가 스트로크 약 10 인치(inches) 부분에서 불연속적 인 변하는 타이어 접힘방향의 변화 등을 고려한 작동기구 특성이고, 19 인치 부분에서 작동력의
급작스런 변화는 작동기 Full Chamber에 설치되 어 있는 제한기의 Snubbing 기능을 나타내고 있 다. 스트로크가 증가할 수록 작동력이 감소함은 착륙장치의 공기역학적 단면적에 비례하는 공력 하중에 의한 영향으로 설명할 수 있다.

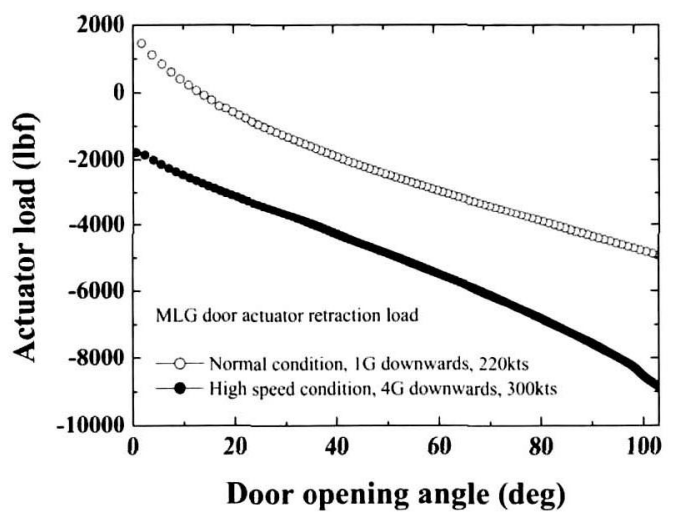

Fig. 7. Variation of the load of the MLG door actuator during retraction.

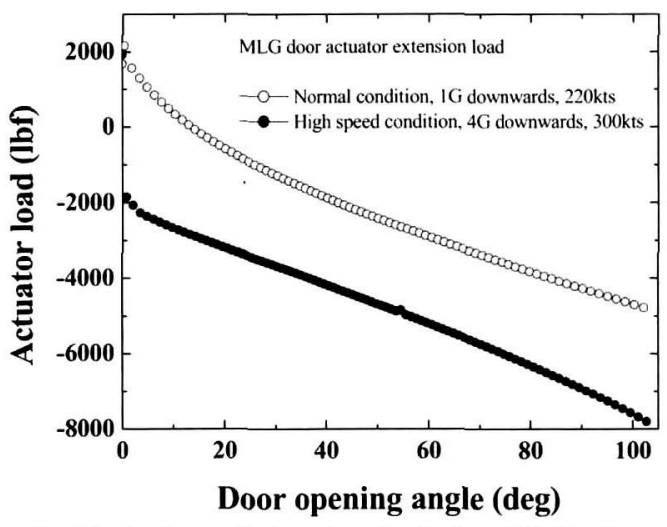

Fig. 8. Variation of the load of the MLG door actuator during extension.

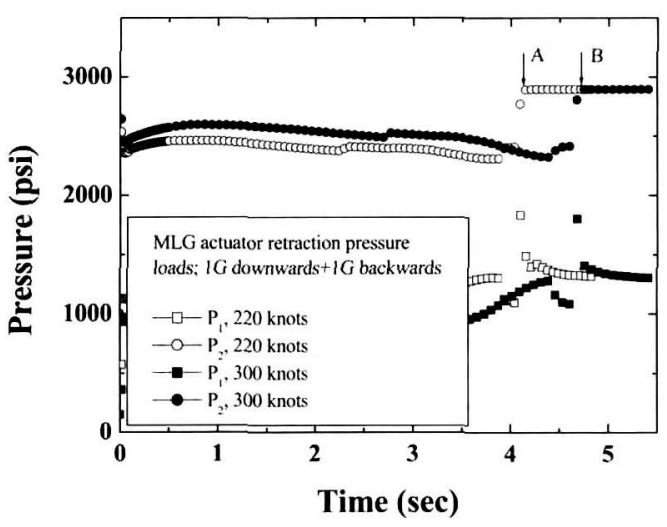

Fig. 9. Variation of the chamber pressure of the MLG actuator during retraction. 


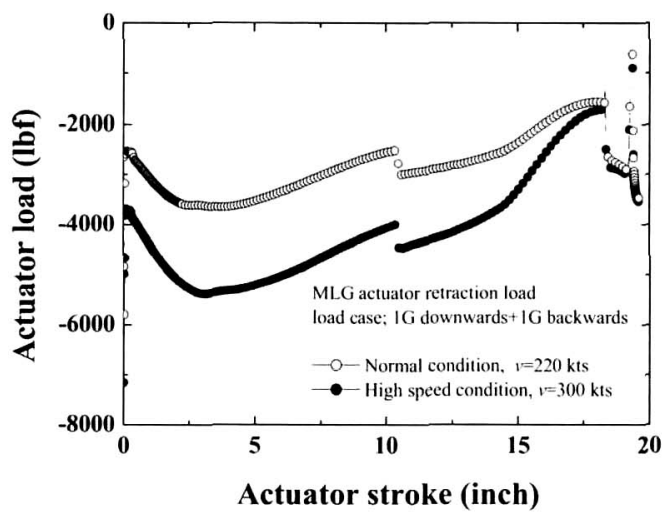

Fig. 10. Variation of the load of the MLG actuator during retraction.

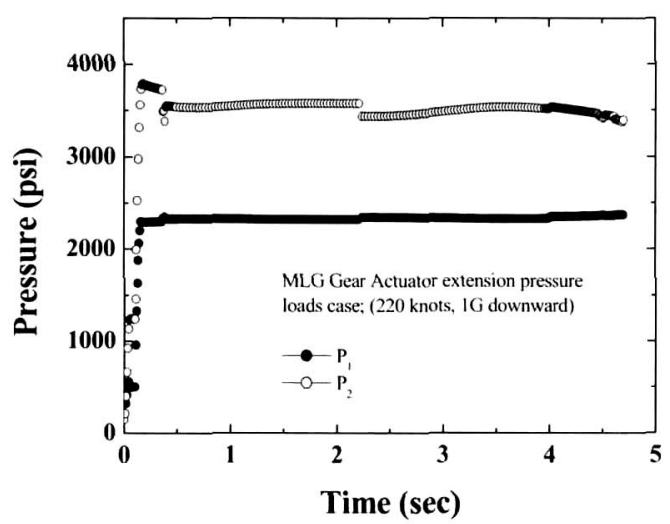

Fig. 11. Variation of the chamber pressure of the MLG actuator during extension.

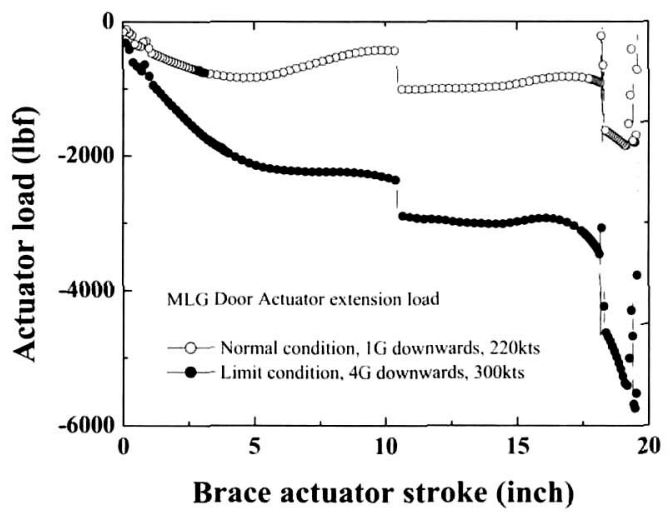

Fig. 12. Variation of the load of the MLG actuator during extension.

Fig. 11, 12는 다양한 항공기 속도조건에서 주 륜 착륙장치의 내림 작동시 작동기 챔버 압력 및 작동력에 대한 해석결과로 내림시 작동기 배출챔 버 압력 $\left(P_{2}\right)$ 이 공급챔버 압력 $\left(P_{1}\right)$ 보다 높아 작동 력은 음부호(-)로 나타난다. 이는 공력 및 기동하
중에 의해 내려가는 주륜 착륙장치의 내림 하중 이 크고 속도가 상대적으로 크기 때문에 작동기 의 피스톤을 끌고 가게 됨에 따라 작동력은 반대 방향으로 작동함을 의미한다. 주륜 착륙장치를 내리는 작동에서는 항공기 속도가 커질수록 작동 력은 빠른 착륙장치 내림을 제지하는 쪽으로 더 크게 작용함을 알 수 있다. 작동기 스트로크 10 인치 부분에서 작동력이 급작스럽게 감소함은 접 힘중 타이어 방향변경에 해당하는 작동기구의 특 성에 의한 현상이며, 19 인치 부분에서 작동력의 급작스런 변화는 원래 착륙장치 올림시 관성에 의한 충격을 줄이기 위하여 설치한 Snubbing 기 능이 착륙장치 내림 초기에도 나타난 현상이다.

Fig. 13은 항공기 속도에 따른 주륜 착륙장치 의 비상 내림 동작에 대한 작동력을 나타내고 있 다. 항공기 속도가 $220 \mathrm{kts}$ 인 경우 공력 및 자중 에 의해 착륙장치 작동력이 내부잠금하중 (claw device)을 초과하여 내림잠금이 (downlock) 작용 한 반면, 항공기 속도가 0 인 경우 단지 자중에

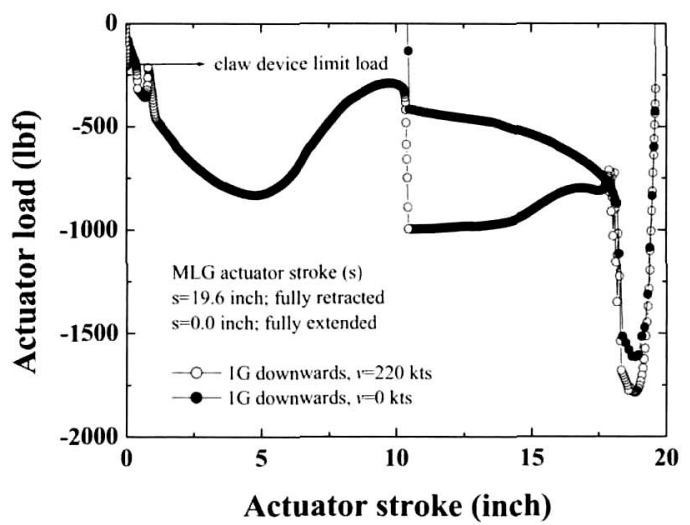

Fig. 13. Variation of the load of the MLG actuator during emergency extension.

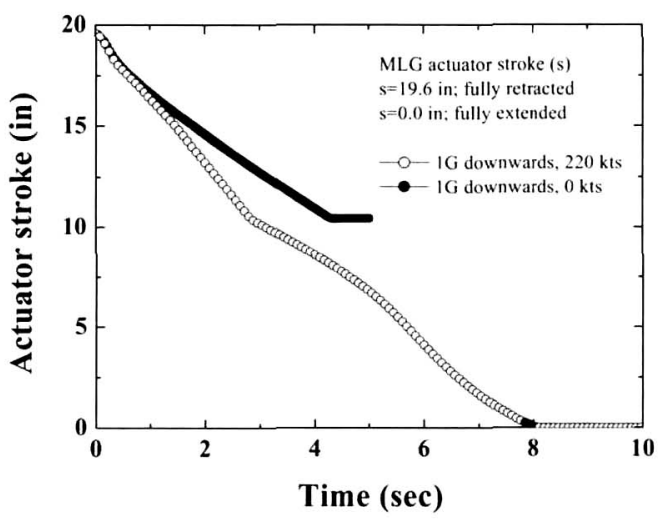

Fig. 14. Variation of the stroke of the MLG actuator during emergency extension. 
의한 작동력은 내부잠금하중 미만으로 내림잠금 작동이 되지 않음을 알 수 있다.

Fig. 14는 시간에 따른 작동기 스트로크의 결 과로 항공기 속도가 $220 \mathrm{kts}$ 의 경우 내림 작동이 가능하나, 속도가 0 인 경우 내림 작동에 실패함 을 확인할 수 있다.

\section{3 온도의 영향}

Fig. 15, 16은 온도의 영향을 분석하기 위하여 상 온과 저온 $\left(-32^{\circ} \mathrm{C}\right)$ 의 경우에 대해 주륜 착륙장치 올 림시 작동기의 작동력과 스트로크를 나타내고 있다.

Fig. 15에서 작동기의 스토로크에 대한 작동력 은 약간의 증가는 있으나 온도의 영향이 거의 없 다. 반면, Fig. 16에 나타낸 바와 같이 상온의 경 우 $\mathrm{A}$ 동안의 올림시간이 저온 $\left(-32^{\circ} \mathrm{C}\right)$ 의 경우는 $\mathrm{B}$ 동안으로 약 $25 \%$ 정도의 올림시간이 증가한다. 따라서 착륙장치 작동기 운용온도는 매우 중요한 설계 변수임을 확인할 수 있다.

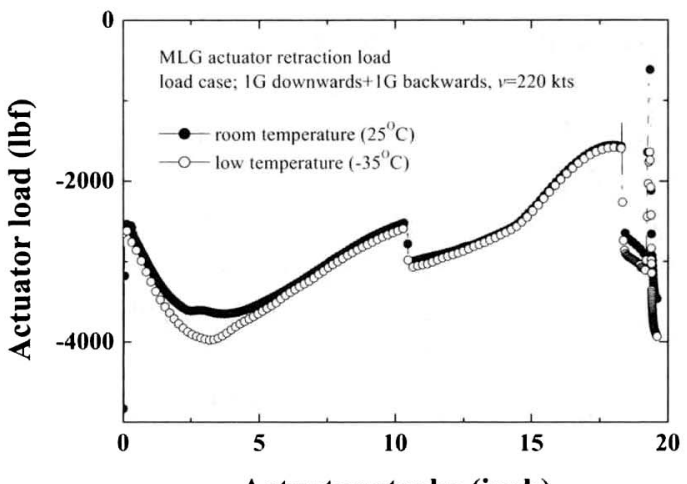

Actuator stroke (inch)

Fig. 15. Variation of the load of the MLG actuator during retraction with various temperature conditions.

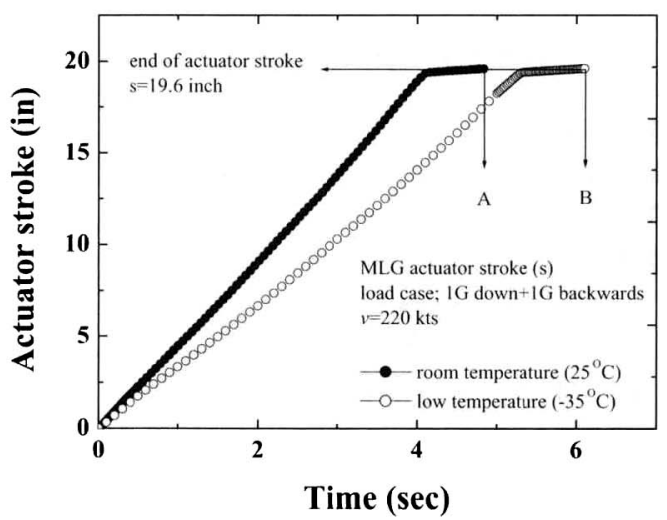

Fig. 16. Variation of the stroke of the MLG actuator during retraction with various temperature conditions.

\section{V. 결 론}

본 연구에서는 $\mathrm{ADAMS}$ 를 활용하여 착륙장치 및 덮개문 작동 동적거동을 해석하는 프로그램을 개발하여 아래의 결론을 얻었다.

1. 설계변수 설정, 유압 압력/유량의 관계 정 의, 운동방정식을 유도하여 다양한 운용/환경조 건을 고려한 기동조건, 공력하중, 온도의 영향에 대한 동적거동 해석결과를 제시하고 분석하였다.

2. 향후 새로운 착륙장치 개발시 범용적인 해 석이 용이할 뿐만 아니라 다양한 운용/환경조건 을 고려한 비행시험의 문제점 발생시 고장탐구 해결에 활용할 수 있다.

3. 향후 착륙장치 지상 및 비행시험 결과와 비 교분석을 통하여 프로그램의 타당성을 입증하는 연구가 필요하다.

\section{참고문헌}

1) N. S. Currey, Aircraft Landing Gear Design: Principles and Practice, American Institute of Aeronautics and Astronautics, Inc., Washington, D.C., 1988.

2) 고한영, 양계병, 정상준, 천명석 "항공기 착륙 장치 작동성 분석 및 측정을 통한 가변형 구동플랩 덮개문 개발연구", 항공기 개발기술 심포지움, 제5 회, pp. 674-691, 1997.

3) 정상준, 고한영, "KTX-1-05 주륜착륙장치 구 동기구 개발", 국방과학연구소 연구보고서 ASDC-501-970789, 1997

4) 임철호, 최영준, “KTX-1-03B/04A 유압시스템 해석 연구", 국방과학연구소 연구보고서 ASDC-401-971293, 1997.

5) 최섭, 이종훈, 조기대, 정창래, "ADAMS를 이 용한 항공기 착륙장치 지상 충격하중 및 동적거동 해석," 한국항공우주학회지 제 30 권 제4호 2002, pp. 114-122.

6) O. Noel and M. Roussarie, "KTX2 landing gear control system, dynamic actuation analysis report", DR49474 issue 2, 2000.

7) H. Zhang, J. Ning and O. Schmelzer, "Integrated landing gear system retraction/ extension analysis using ADAMS", 2000 International ADAMS User conference.

8) 김종길, 하태완, “ADAMS를 이용한 차량시스 템의 충격진동 해석", 국방과학연구소 연구 보고 서, MSDC-519-990104, 1999.

9) ADAMS User's Manual, Mechanical Dynamics, 1998. 